\title{
O Voluntariado Social e suas Interrelações com a Sustentabilidade
}

The Social Volunteering and their Interpelationships with Sustainability

\author{
Rosangela Cenci \\ Rosaria Maria Ferreira Silva ${ }^{2}$ \\ Simone Sehnem ${ }^{3}$ \\ Eliane Salete Filippim ${ }^{4}$
}

\section{Resumo}

O artigo buscou identificar as principais dificuldades encontradas pela Associação Vida Cidadã (AVIC), na ótica do voluntariado. O estudo consiste em uma pesquisa de abordagem qualitativa, do tipo descritiva, cujo procedimento consiste em um estudo de caso. Foi possível observar que, na visão dos voluntários sujeitos da pesquisa, a principal dificuldade existente na organização é a sustentabilidade financeira. Os voluntários da organização vêem a humanização como o principal ponto forte da AVIC. Evidencia-se a predominância do entendimento de sustentabilidade pela integração das sustentabilidades (econômica, social, ambiental) com tendência de preferência para a dimensão social.

Palavras-chave: Voluntariado, Sustentabilidade, Terceiro Setor.

\begin{abstract}
The paper aims to identify the main difficulties encountered by the Association Citizen Life ( $A V I C)$, the viewpoint of volunteering. The study consists of a qualitative research, descriptive, whose procedure consists of a case study. It was observed that, in the perspective of the volunteer research subjects, the main difficulty in your organization's financial sustainability. The volunteers of the organization view humanization as the main strength of AVIC. This confirms the predominance of understanding the integration of sustainabilities sustainability (economic, social, environmental) with a tendency of preference for the social dimension.
\end{abstract}

Keyword: Volunteering, Sustainability, Third Sector.

\footnotetext{
1 fraternura@hotmail.com. Mestranda em Administração na Universidade do Oeste de Santa Catarina - UNOESC. Rua Nereu Ramos, 3777, Seminário, CEP: 89803-000 - Chapeco, SC - Brasil.

2 rosariamferreira@yahoo.com.br. Mestranda em Administração na Universidade do Oeste de Santa Catarina - UNOESC. Rua Nereu Ramos, 3777, Seminário, CEP: 89803-000 - Chapeco, SC - Brasil.

3 simonesehnem_adm@yahoo.com.br. Professora da Universidade do Oeste de Santa Catarina - UNOESC. Doutora em Administração e Turismo pela Universidade do Vale do Itajaí - UNIVALI. Rua Nereu Ramos, 3777, Seminário, CEP: $89803-$ 000 - Chapeco, SC - Brasil.

${ }^{4}$ eliane.filippim@unoesc.edu.br. Professora da Universidade do Oeste de Santa Catarina - UNOESC. Doutora em Engenharia de Produção pela Universidade Federal de Santa Catarina - UFSC. Rua Nereu Ramos, 3777, Seminário, CEP: 89803-000 - Chapeco, SC - Brasil.
}

\section{Revista Administração em Diálogo} ISSN 2178-0080 


\section{Introdução}

Nas últimas décadas o tema da sustentabilidade nas suas dimensões social, econômica e ambiental tem frequentado a agenda tanto dos estudos científicos quanto da gestão de políticas públicas e congregado atores individuais, institucionais, públicos e privados. A promoção e a efetivação da sustentabilidade desafia um conjunto de iniciativas e ações da sociedade civil [sobretudo do Terceiro Setor] e dos governos que, numa visão para além daquela restrita ao público de cunho estatal, pensa e age em favor do desenvolvimento sustentável dos territórios e da coletividade. Uma das estratégias de mobilização de forças é o voluntariado que permite a ação de indivíduos de maneira não remunerada, em organizações que têm comprovados objetivos de atendimento ao interesse público.

Neste sentido, o tema deste estudo tem foco na atividade de voluntariado na sua relação com as dimensões da sustentabilidade. O fenômeno estudado foi observado numa organização sem fins lucrativos que teve o início de suas atividades no ano de 2008, no município de Xanxerê, Santa Catarina, Brasil. Naquele ano reuniram-se lideranças daquela comunidade para discutir um modelo de educação alternativa à formal, que atendesse necessidades emergentes do município e se dedicasse, prioritariamente, às pessoas em vulnerabilidade social. Esta mobilização inicial resultou, em 2009, na implantação do Projeto Social da Associação Vida Cidadã (AVIC). Esta Associação adotou desde então, como linha central, a realização de atividades educativas, oferecendo cursos profissionalizantes, visando à inclusão social e evitando práticas meramente assistencialistas.

A escolha do estudo deste caso recaiu sobre a AVIC devido a algumas particularidades metodológicas adotadas por esta Associação. Estas particularidades compõem a sua identidade com a sua inserção social e são: a) formação humana (valores, liderança, motivação, cidadania, comportamento, entre outros) fornecida nos cursos profissionalizantes que é praticamente a mesma da carga horária oferecida na formação técnica; b) itinerância, ou seja, fornecer o curso no bairro, no local onde moraram os cursistas; c) cursos inovadores que atendam as necessidades emergentes; d) trabalho voluntário dos ministrantes dos cursos, com capacitação para tal. 
Neste contexto, este estudo teve como objetivo geral identificar quais as principais dificuldades encontradas pela AVIC na visão dos voluntários que atuam na entidade. Como objetivos específicos, buscou-se: verificar qual a visão de sustentabilidade que os voluntários possuem; avaliar os principais pontos fortes da AVIC na visão dos voluntários; e observar a percepção que eles têm referente às práticas de sustentabilidade na AVIC. Desta maneira, a questão que norteou o estudo foi: Quais são as principais dificuldades encontradas pela AVIC, na visão do voluntariado?

A relevância deste estudo se justifica uma vez que os seus resultados poderão ser utilizados como fonte para a gestão desta e de outras organizações do Terceiro Setor que atuam com projetos sociais e que têm como colaboradores os voluntários. O estudo pode propiciar ainda aprendizagem no que se refere à sustentabilidade da organização estudada, a AVIC, destacando a interrelação e complementaridade existente entre o voluntariado em uma organização do Terceiro Setor, por meio de uma gestão social com participação e planejamento, tendo como objetivo maior a busca pela sustentabilidade.

Com relação aos procedimentos metodológicos, trata-se de uma pesquisa de abordagem qualitativa, realizada por meio de um estudo de caso com objetivo descritivo. Os dados foram coletados de múltiplas fontes e tratados de maneira a cotejá-los, sejam aqueles obtidos pela observação de campo, pela análise de documentos ou pela aplicação de questionários com perguntas semi-estruturadas.

\section{Sustentabilidade, Parcerias, Terceiro Setor e Trabalho Social}

As organizações do Terceiro Setor fazem parte da trajetória humana na tentativa de superação dos desafios enfrentados naqueles processos de intervenção social que visam amenizar os efeitos da exclusão social, desigualdade e desemprego. Estas organizações têm se desenvolvido por meio de parcerias e alianças entre os atores afins em seu entorno. Procuram ocupar uma lacuna deixada pelo Estado e também pelo setor privado.

\section{Sustentabilidade}

É perceptível que o conceito de sustentabilidade está cada dia mais incorporado nas organizações, contudo, nem sempre se observa que se passa do conceito à prática 
com a mesma rapidez. A concepção de desenvolvimento adotada neste estudo é aquela que apregoa a conciliação das dimensões que fazem parte do triple botton line da sustentabilidade: social, econômica e ambiental.

Quadro I: Dimensões da sustentabilidade

\begin{tabular}{|l|l|}
\hline Dimensão & Características \\
\hline \multirow{3}{*}{ Sustentabilidade social } & - Criação de postos de trabalho; \\
& - Qualificação profissional; \\
& - Produção de bens dirigidas ao atendimento das necessidades básicas; \\
& - Desconcentração espacial de atividades e de população; \\
& - Democratização do poder local/regional.
\end{tabular}

Fonte: Filippim (2008) adaptado de Montibeller-Filho (2002).

Nos termos de Elkington (2004), o equilíbrio dinâmico entre as três dimensões (econômica, social e ambiental), poderá ser alcançado quando a organização considerar a integração efetiva destes pilares na sua estratégia e na sua ação, já que a construção da sustentabilidade é um desafio que só pode ser enfrentado de maneira integrada e com o efetivo engajamento de todos os atores envolvidos.

Da mesma forma, as transformações exigidas para um modo de vida sustentável são profundas e dependem do entrosamento destes atores, que possuem diferentes capacidades, conhecimentos, experiências, repertórios, mas que estão dispostos a compartilhá-los pelo bem comum.

Conforme Seiffert (2OII) existem algumas prioridades de intervenção para o alcance do desenvolvimento sustentável, tais como: diminuir a pobreza, diminuir a desigualdade social, praticar agricultura sustentável, aumentar a eficiência energética, limitar os gases de estufa, erradicar a fome e outras. Estas prioridades já são consenso entre vários países, organizações e atores do desenvolvimento. Ainda segundo Seiffert (2OII), a crescente expansão da capacidade produtiva dos ecossistemas antrópicos, que gradativamente induziram a uma degradação ambiental sem precedentes, levaram o

\section{Revista Administração em Diálogo} ISSN 2178-0080 
homem a perceber como sua saúde e qualidade de vida estavam sendo afetadas pela poluição. Isto fez o homem repensar seu modelo de desenvolvimento baseado no crescimento econômico, que deixava as questões socioambientais em segundo plano. Surgiu então a opção de desenvolvimento com sustentabilidade, cujo conceito foi sendo amadurecido ao longo dos anos.

A preocupação com a sustentabilidade vem se tornando cada vez mais importante e presente na vida de todos os cidadãos em todos os países do mundo. A partir de I95O, vários acidentes ambientais começaram a chamar a atenção da sociedade para o ritmo da degradação e principalmente para o fato de que a qualidade de vida, e mesmo a sobrevivência, do homem no planeta está condicionada ao cuidado com ele. De acordo com Moura (2002), o homem começou a repensar sua posição em relação ao uso dos recursos naturais em seu entorno, o que levou a um amadurecimento dos conceitos de desenvolvimento e educação ambiental.

Especialistas da área ambiental buscavam soluções, analisando de forma crítica o modelo existente de crescimento econômico, de maneira à melhor orientá-lo para a sustentabilidade. Em I968, conforme Tinoco e Kraemer (2004) foi criado o Clube de Roma, que estudou o impacto global das interações dinâmicas entre a produção industrial, a população, o dano no meio ambiente, o consumo de alimentos e o uso de recursos naturais. Em I972, aconteceu a primeira manifestação dos governos de quase todo o planeta para discutir as consequências da economia sobre o meio ambiente, quando começou a ser delineado o conceito de desenvolvimento sustentável. Esta foi a Conferência das Nações Unidas sobre o Meio Ambiente Humano, em Estocolmo Suécia, com a participação de II3 países, 250 organizações não governamentais e vários organismos da ONU. Esta iniciativa gerou um Plano de Ação Mundial com o objetivo de orientar o uso racional dos recursos naturais e a melhoria no ambiente humano.

Conforme Fernandes (2005), em 1987 foi publicado o Relatório Brundtland, que indicava a desigualdade existente entre os países e a pobreza como uma das principais causas dos problemas ambientais, contribuindo para divulgar o conceito de Desenvolvimento Sustentável. O Relatório apregoava que o desenvolvimento econômico de hoje deve acontecer sem comprometer as necessidades das gerações futuras. 
Em 1992, ocorreu a Rio $9^{2}$ ou Eco 92, a Conferência das Nações Unidas para o Meio Ambiente e Desenvolvimento (CNUMAD), que teve como objetivo discutir temas ambientais mundiais e propor soluções potenciais. Surgiu a Agenda 2I, com diretrizes gerais para processos de gestão em nível federal, estadual e municipal, tendo como objetivos principais a erradicação da pobreza, a mudança dos padrões insustentáveis de produção e consumo de recursos. Em 1997, foi assinado o Protocolo de Kyoto, que estabeleceu como meta para $3^{8}$ países industrializados reduzir as emissões de gases do efeito estufa. Em 2002, ocorreram a Rio ${ }^{+}$IO na África do Sul, donde resultou a Declaração Política: O Compromisso de Johanesburgo por um Desenvolvimento Sustentável. Em 20I2, ocorreu, no Rio de Janeiro, a Rio ${ }^{+} 2 \mathrm{O}$ que, entre críticas e ovações, foi encerrada após a divulgação do documento: O Futuro Que Nós Queremos, que foi assinado pelos chefes de Estado e de governo.

Deste modo, a sustentabilidade é um grande desafio para o Século XXI. Ao se reconhecer as diversas necessidades de várias nações, as decisões e ações de todos os atores envolvidos serão determinantes para o futuro das gerações. Segundo Sachs (2008), os desafios do desenvolvimento sustentável, de proteger o meio ambiente, estabilizar o crescimento demográfico mundial, reduzir as diferenças entre ricos e pobres e acabar com a miséria serão o centro das atenções. E estes desafios exigirão negociação e acomodação entre as visões de mundo criadas pelos atores e só poderão ser alcançados com uma mobilização global, fundamentada com a interação e cooperação entre todos, em muitos casos, voluntária.

Para Capra (2005), o conceito de sustentabilidade deve ser uma construção consensual entre os indivíduos, as organizações e as nações. Na mesma linha, para Jacobi (I999), a sustentabilidade precisa estimular, de forma permanente, as responsabilidades éticas, sendo também reconsiderados os aspectos relacionados com a equidade e a justiça social. A noção de sustentabilidade torna imprescindível uma inter-relação entre justiça social, qualidade de vida, equilíbrio e a necessidade de desenvolvimento com capacidade de suporte.

Sachs (2002) classifica a sustentabilidade em cinco dimensões, que permitem visualizar os elementos envolvidos e afetados pelas interações existentes em um contexto de desenvolvimento territorial: I) Sustentabilidade Social: refere-se ao alcance de nível 
razoável de homogeneidade social. A meta é construir uma sociedade com maior equidade na distribuição de renda e bens, reduzindo a desigualdade social e acesso aos serviços e recursos sociais. 2) Sustentabilidade Econômica: o desenvolvimento econômico deve ser alcançado através do gerenciamento e alocação de recursos mais eficientes e de contínuos investimentos públicos e privados. A eficiência econômica deve ser avaliada em termos macrossociais. 3) Sustentabilidade Ecológica: refere-se ao uso do potencial de recursos dos vários ecossistemas com o menor dano possível ao sistema de sustentação da vida, limitar o uso de combustíveis fósseis e produtos não renováveis e/ou substituí-los por produtos renováveis e/ou abundantes, reduzir o volume de poluição e resíduos, incentivar a reciclagem, incrementar pesquisas em novas tecnologias para reduzir a produção de resíduos e para uso eficiente de recursos no desenvolvimento, promover a autolimitação no uso de recursos não renováveis pelos países ricos e pelos indivíduos em nosso planeta e definir normas adequadas de proteção ambiental. Importância da conscientização ambiental através da educação. 4) Sustentabilidade Espacial: refere-se a uma melhor distribuição territorial e das atividades humanas. Configurações urbanas e rurais balanceadas, melhoria do ambiente urbano, superação das disparidades inter-regionais e criação de uma rede de reservas naturais e de biosfera, para preservar a biodiversidade. O foco é uma configuração rural-urbana equilibrada. 5) Sustentabilidade Cultural: referente a processos que busquem mudanças respeitando a cultura, procura das raízes endógenas, o equilíbrio entre respeito à tradição e inovação, ou seja respeito às especificidades culturais.

Estas cinco dimensões, propostas por Sachs (2002), neste estudo foram concentradas nas três: social, ambiental e econômica. A sustentabilidade, integrando suas diferentes dimensões, contribui para a redução das desigualdades sociais, iniquidade e exclusão que atingem inúmeros grupos de seres humanos, dando assim oportunidade para que tenham uma melhor qualidade de vida (PAULA, 200o). A superação dos desafios na busca pela sustentabilidade só será possível por meio de redes, alianças e parcerias para um trabalho social onde se busca com maior mobilização e participação de pessoas a amenização das mazelas sociais, econômicas e ambientais.

\section{Alianças para o trabalho social}


As alianças proporcionam oportunidades únicas para o desenvolvimento de força com um conjunto amplo de parceiros. As organizações precisam atender as necessidades urgentes de recursos, de novas habilidades e de tecnologia, que poucas organizações sozinhas conseguem se sustentar (LEWIS, 1992). Existem inúmeras vantagens para as alianças que devem fundamentar-se em cooperação mútua entre as partes envolvidas, na qual a confiança recíproca é condição central. Conforme Noleto (2000), nas alianças, as organizações que poderiam atuar de forma independente decidem fazê-lo conjuntamente, motivadas pela consciência da magnitude da complexidade da ação a ser compreendida. Assim, as organizações trabalham com a ideia de longo prazo, de pacto, de união mais estável e permanente para a resolução de problemas complexos como aqueles originados nas demandas de populações em maior vulnerabilidade social.

Fischer (2002) aponta que a criação e o desenvolvimento das alianças não são processos lineares e fáceis, mas que, ao contrário, colocam vários desafios para quem os opera, assim como para quem os analisar e gerar conhecimentos que propiciem sua reprodução.

De acordo com Sampaio (I999), parcerias é um pacto voluntário entre diversos atores que se firma em torno de interesses comuns e convergentes, cujo resultado permite a geração e redistribuição de benefícios dentro da expectativa de cada ator. Afirma ainda que parceria requer pensar e agir juntos, identificar o que cada um faz melhor, sem que isso implique em confusão de papéis ou abdicação da autonomia e responsabilidade inerente a cada parceiro.

Conforme Noleto (2000), nas parcerias busca-se superar necessidades de modo a promover a inter-complementariedade de recursos e capacidades entre organizações parceiras. É somar forças para descobrir novas maneiras de otimizar recursos, conhecimentos, potencialidades e capacidades, para encontrar a melhor maneira de fazer algo.

Ao analisar os requisitos que norteiam o êxito dos processos de desenvolvimento local e de sua gestão, percebe-se que é fundamental a consolidação de parcerias entre os diversos atores sociais, e que estas parcerias existam de forma que cada ator se relacione com os demais em condições de igualdade. A intensa valorização das parcerias exige 
novas posturas, uma delas é a capacidade de articular atores individuais e institucionais presentes na sociedade, sobretudo aqueles do chamado Terceiro Setor.

\section{Terceiro Setor}

Observa-se o crescimento de atividades voluntárias organizadas e a criação de inúmeras organizações privadas sem fins lucrativos ou não-governamentais. Os cidadãos estão criando e formando associações, fundações e instituições similares para atuar com prestação de serviços sociais, para defender os direitos civis, promover o desenvolvimento econômico, social e ambiental e atuar na realização de várias ações ainda não realizadas ou deixadas sob a responsabilidade do Estado. Conforme Fernandes (I994) Terceiro Setor é o termo que vem encontrando maior aceitação para designar o conjunto destas iniciativas e ações da sociedade, na busca por melhores condições de vida num determinado território. Para Salomon (I998) o alcance e o poder de força deste fenômeno são relevantes.

O Terceiro Setor é uma importante rede de organizações privadas autônomas, onde não existe a distribuição de lucros para diretores e acionistas, busca atender necessidades públicas, mesmo estando à margem do aparelho formal do Estado. É o reflexo de mudanças sociais e tecnológicas aliadas à constante não confiança na capacidade do Estado. (SALOMON, I998)

O termo Terceiro Setor é ainda muito novo no ordenamento jurídico brasileiro, carecendo de uma definição legal. De acordo com Camargos (2008) no Código Civil Brasileiro, em seus artigos 53 a 62, existe apenas a qualificação para as entidades jurídicas já existentes sem fins lucrativos que prestam atividades relacionadas ao Terceiro Setor. O termo sugere um terceiro elemento.

Cardoso (I997) e Kisil (I997) consideram o setor público como o primeiro setor e o mercado ou setor privado (atividades lucrativas) como segundo setor e Terceiro Setor como não governamental, voluntário, privado. Já Fernandes (I994) considera como primeiro setor o mercado, o segundo setor o governo e o Terceiro Setor como uma conjunção entre público e privado.

Coelho (2002) afirma que a maioria dos autores americanos considera o mercado como primeiro setor e o governo como segundo. Para Falconer (I999), mais do 
que um conceito rigoroso ou um modelo solidamente fundamentado em teoria, o Terceiro Setor no Brasil é uma ideia-força, um espaço mobilizador de recursos, de reflexão e prioritariamente de ação. É usado para se referir à ação social das empresas, ao trabalho voluntário de cidadãos e às organizações do poder público, privatizadas na forma de fundações, associações e organizações sociais.

Para Salomon e Anheier (1992), as organizações do Terceiro Setor apresentam cinco características essenciais: são formais, privadas, independentes, não fazem distribuição de lucros e devem comportar um certo nível de participação voluntária. França Filho (2002) acrescenta mais duas características: as organizações não devem ser políticas (no sentido restrito do termo, ou seja, excluem-se os partidos políticos) e nem devem ser confessionais (ou seja, exclui-se qualquer gênero de organização religiosa). Salomon (I998) alerta que, mesmo tendo uma validade fundamental e uma propalada flexibilidade, é importante reconhecer outro aspecto importante: o fato de que organizações sem fins lucrativos continuam sendo organizações. E, à medida que crescem em escala e complexidade, são vulneráveis a todas as limitações que incomodam outras instituições burocráticas, tais como rotinização, morosidade, falta de sensibilidade. Destaca ainda que não estão imunes às tensões inevitáveis entre flexibilidade e efetividade.

No Brasil, o Terceiro Setor nasceu sob o signo da parceria. São vários autores contribuindo para fortalecer o setor e formar uma imagem do seu papel, como setor capaz de fazer frente aos problemas sociais mais urgentes e necessários no país (FACONER, 1999).

Para Salamon (1997) existem no Brasil diversas denominações para as organizações deste setor: setor sem fins lucrativos, setor da sociedade civil, setor voluntário, setor social-econômico, setor ONG, setor de caridade e outras. Tem-se como exemplos tradicionais deste setor, as Santas Casas de Misericórdia, as obras sociais, e, mais recentemente, as ONGs como resultantes dos novos movimentos sociais que surgiram a partir dos anos 1970 .

O Terceiro Setor é composto por organizações de natureza privada, sem fins lucrativos, que possuem objetivos sociais ou de interesses públicos, possuem autonomia 
e administração próprias, têm como objetivo a atuação voluntária junto à sociedade civil, visando o bem-estar social de todos (CAMARGOS, 2Oo8).

Em comparação com outros tipos de organizações, Kisil (I997) afirma que o seu corpo técnico, normalmente, é formado por voluntários que possuem um grande compromisso com o desenvolvimento social, são organizações orientadas para ação, atuam de forma flexível, inovadora, rápida e no território onde se encontram. Coloca ainda que possuem um papel de ligação entre o cidadão comum com entidades e organizações que podem participar da solução de problemas identificados. De um lado prestam ou fornecem algum tipo de serviço ou utilidade à comunidade, do outro lado precisam de recursos para seus programas e suas ações, que podem vir de diferentes formas, seja através de doações, seja de patrocínios, incentivos e outros meios. Apesar das dificuldades enfrentadas pelo Terceiro Setor, a atuação crescente do voluntariado tornou-se relevante para o fortalecimento institucional e aperfeiçoamento da sua gestão.

\section{O Papel do Voluntariado}

No Brasil, a Lei Federal nº 96o8, de r998, que dispõe sobre o voluntariado, em seu artigo $\mathrm{I}^{\mathrm{o}}$, considera o serviço voluntário como: “a atividade não remunerada, prestada por pessoa física a entidade pública de qualquer natureza, ou a instituição privada de fins não lucrativos, que tenha objetivos cívicos, culturais, educacionais, científicos, recreativos ou de assistência social, inclusive mutualidade”. Em seu Parágrafo Único define que o serviço voluntário não gera vínculo empregatício, assim como também não gera qualquer obrigação trabalhista, previdenciária ou afim.

Para a ONU, Organização das Nações Unidas, (2009), o trabalho voluntário beneficia tanto a sociedade em geral como cada ser humano por meio do reforço da solidariedade, da confiança e da reciprocidade entre os cidadãos, criando oportunidades de participação. Para Ban Kin-Moon, Secretário-Geral da ONU (2009), o trabalho voluntário está entre os ativos mais importantes da sociedade. É uma fonte de força comunitária, superação, solidariedade e coesão social, que pode trazer uma mudança social positiva com a participação de todos, além de promover o respeito à diversidade e a igualdade. 
Conforme Camargos (2008), o trabalho religioso na sociedade ocidental e também no Brasil, foi o precursor do trabalho voluntário. Com o passar dos anos, o voluntariado foi ganhando mais corpo, destacando-se da atividade religiosa para abranger um campo mais extenso. A fundação da Santa Casa de Misericórdia na então Capitania de São Vicente no ano de I543 pode ser considerada marco inicial do trabalho voluntário no Brasil.

O voluntariado expressa, em sua essência, dois tipos de motivação: a convicção de que a solidariedade é fator básico para o amadurecimento pessoal e a percepção cada vez maior de que a humanidade somente subsistirá se converter a solidariedade em um princípio essencial do desenvolvimento humano (ROCA, I994).

Para Teodósio (2002), a lógica do trabalho voluntário tem sido entendida como "não remunerado monetariamente". Contudo, existem outros tipos de remuneração como, por exemplo, de ordem ideológica, emocional, afetiva, ética, religiosa e profissional. As razões que levam uma pessoa a trabalhar como voluntário numa organização é diferente daquelas razões que a influenciam para o trabalho remunerado. Trata-se de oportunidades de crescimento pessoal e de conhecimento, ao contrário da relação formal inerente ao trabalho de natureza comercial, convivendo com pessoas sob contrato social espontâneo (SOUZA; MEDEIROS, 2OI2).

De acordo com Soares (2OI2), o voluntariado é o resultado de um contexto de uma sociedade que se integra em busca da diminuição das injustiças e das desigualdades sociais. Tendo como base as relações de proximidade, com o objetivo de prestar apoio social e pessoal aos atores, famílias ou organizações de um determinado território. Ainda Soares (2OI2), o valor especial do voluntariado deriva de uma contribuição voluntária para moldar a sociedade. Não significa substituir o trabalho pago pelo trabalho não pago, ou substituir o papel do Estado, trata-se de uma contribuição individual e altruísta, de uma participação ativa dos cidadãos para um bem comum.

Para Coelho (2002), existem duas movimentações básicas para as pessoas atuarem como voluntários: o altruísmo e o interesse próprio. É possível que isto ocorra porque o indivíduo se sente compelido a ajudar os mais necessitados e em piores condições de vida, quando adere a uma causa social ou assume suas responsabilidades com a comunidade. Segundo a literatura, existem outros motivos que podem orientar 
para o voluntariado, mais ligados a questões profissionais e de desenvolvimento de habilidades valorizadas pelo mercado de trabalho. Algumas organizações se interessam por pessoas que atuam como voluntários, pois atuando no voluntariado desenvolvem criatividade, aprimoram técnicas de gerenciamento, sabem cumprir mais de uma função, partindo do princípio de que as instituições onde atuam como voluntários funcionam com poucos recursos.

O voluntariado precisa ser um processo transparente e natural e que gere satisfação ao voluntário. De acordo com Dohme (2OOI), alguns dos motivos que levam uma pessoa ao trabalho voluntário são: a) Alcançar objetivos sociais, pois o voluntário é aquele que, além de objetivos pessoais, possui uma visão própria da realidade social em seu entorno e projeta objetivos para a comunidade; b) Ter uma participação realmente efetiva na obtenção de objetivos sociais; c) Buscar a aceitação de um grupo.

Observa-se que cada vez mais o voluntariado tem aumentado o número de adeptos. As pessoas e as organizações têm se mobilizado em favor de causas sociais, com o intuito de promover cidadania e amenizar as diferenças socioeconômicas existentes. Conforme consta no Manual do Voluntariado do Instituto ETHOS (2006), ser voluntário significa mais do que sanar necessidades imediatas das pessoas, dar comida a quem tem fome, um agasalho para quem sente frio ou cuidar de pessoas doentes. O voluntariado é conscientização das pessoas, é também a mobilização de grupos sociais marginalizados na defesa de seus direitos e muitas outras ações no campo da cidadania.

Para Fischer e Falcone (I999), uma organização deve influenciar o seu entorno social. Investimentos em ações de voluntariado certamente trazem benefícios para a própria organização, para seus funcionários e para a coletividade como um todo. O trabalho voluntário é mais bem assimilado pelos empregados das organizações socialmente responsáveis e que estimulam uma cultura favorável ao voluntariado. Programas de voluntariado estão alinhados com a gestão de pessoas na organização e como instrumento para o desenvolvimento de habilidades interpessoais, liderança e trabalho em equipe, propiciando um clima organizacional positivo.

O Programa de Voluntários das Nações Unidas (VNU), criado pela ONU em sua Assembleia Geral de I970, administrado pelo PNUD, promove o voluntariado para a paz e para o desenvolvimento. Reconhece o voluntariado dentro da sua diversidade e entende 
que é universal e inclusivo, fomentando valores que envolvem escolha própria, compromisso, engajamento e solidariedade. Os efeitos do voluntariado tendem a aumentar a confiança, a solidariedade e a reciprocidade entre cidadãos. Todos os anos, mais de 7 mil pessoas de mais de I70 nacionalidades, qualificadas e com grande experiência profissional, servem como voluntários nas Nações Unidas em mais de I4O países, contribuindo assim para o alcance dos Objetivos de Desenvolvimento do Milênio, contribuindo para a redução da pobreza, para a promoção de políticas ambientais, para a luta contra o aumento de doenças como HIV/AIDS. No Brasil, o VNU atua desde $199^{8 .}$ É um programa em crescimento, de cooperação com projetos de diferentes parceiros em todo o país, com o objetivo de melhorar as condições de vida em comunidades pobres e promover desenvolvimento.

Conforme já observado, os motivos que levam as pessoas ao voluntariado são variados. Para Souza e Medeiros (2012), existe uma Hierarquia do Trabalho Voluntário, que seria classificada em cinco níveis, os 5 As, conforme Quadro 2.

Quadro 2: Hierarquia do trabalho voluntário

\begin{tabular}{|l|l|}
\hline \multicolumn{1}{|c|}{ Nível } & \multicolumn{1}{c|}{ Característica } \\
\hline Nível I: Altruísta & $\begin{array}{l}\text { Retrata a percepção subjetiva de auto sacrifício por parte do voluntário, } \\
\text { envolvendo risco, insalubridade e periculosidade, sob a perspectiva da } \\
\text { consciência de espécie e de questionamento em torno das condições } \\
\text { gerais de vida de seres humanos. }\end{array}$ \\
\hline Nível II: Afetivo & $\begin{array}{l}\text { Reúne motivos relativos ao sentimento de auxílio a sujeitos e comunidades } \\
\text { em situações de exceção, via fornecimento de apoio direto aos menos } \\
\text { aptos e prósperos, como: idosos, crianças, desabilitados e pacientes em } \\
\text { hospitais, estando o voluntário interessado no resgate da cidadania. }\end{array}$ \\
\hline Nível III: Amigável & $\begin{array}{l}\text { Contempla motivos vinculados à avaliação subjetiva de contribuição para o } \\
\text { bem-estar social, e de desafortunados em particular, sob uma perspectiva } \\
\text { amistosa, em que o voluntário se sente compartilhando algo próprio com } \\
\text { alguém. }\end{array}$ \\
\hline Nível IV: Ajustado & $\begin{array}{l}\text { Reúne motivos de uma forma específica de aprimoramento social não } \\
\text { centrada em temas cruciais ou aflitivos, mas que, de alguma forma, } \\
\text { transmite ao voluntário a sensação de estar, simultaneamente, } \\
\text { promovendo a si próprio e a vida do seu receptador. }\end{array}$ \\
\hline Nível V: Ajuizado & $\begin{array}{l}\text { Congrega motivos centrados na sensação de privilégios, de status e de } \\
\text { proteção, estando o voluntário interessado na construção e na projeção da } \\
\text { autoimagem e da promoção pessoal com os indivíduos e as coletividades. }\end{array}$ \\
\hline
\end{tabular}

Fonte: Adaptado de Medeiros (2OI2).

Para Soares (2012), o valor intrínseco ao voluntariado transcende o da prestação de serviços e a satisfação de necessidades sociais. Existem valores que emergem com o voluntariado, tais como o desejo de se sentir útil e a defesa do bem comum. O

\section{Revista Administração em Diálogo} ISSN 2178-0080 
voluntariado pode contribuir para o desenvolvimento de uma forma da sociedade que reforça o sentido de solidariedade e favorece o acolhimento e a integração dos indivíduos na comunidade na qual estão inseridos.

\section{Metodologia}

A abordagem deste estudo é qualitativa, pois, segundo Godoy (I995), a pesquisa qualitativa exige o entendimento do fenômeno dentro do seu contexto. Ainda, a pesquisa qualitativa guarda certo grau de subjetividade e serve a objetivos complexos de fronteiras pouco estabelecidas como é o caso do tema do voluntariado. Para Godoy (2005), na pesquisa qualitativa a utilização de documentos de natureza pessoal ou oficial capta atos e gestos que apoiam e compõem o conjunto de dados coletados.

Trata-se de um estudo de caráter descritivo, visto que as pesquisadoras pretendiam uma primeira aproximação e compreensão do processo do voluntariado. Para tanto, escolheu-se o procedimento do estudo de caso que, segundo Yin (2005), é uma investigação empírica singular. O caso é único, visto que tem foco no estudo da percepção dos voluntários que atuam na Associação Vida Cidadã (AVIC), no município de Xanxerê (SC). Este caso foi escolhido intencionalmente e orientado pelos valores das pesquisadoras, uma vez que na pesquisa qualitativa admite-se que o conjunto de suas crenças afeta a escolha do que estudar, bem como do método. Neste sentido, o caso foi eleito devido ao seu componente humanístico que parece resguardar este que é um dos elementos caros ao desenvolvimento sustentável na sua dimensão social e de mais rara observação empírica em projetos sociais, bem como pelo seu claro combate ao assistencialismo.

Os procedimentos de coleta de dados foram realizados em múltiplas fontes: observação de campo, aplicação de questionários e análise de documentos. A observação se deu em junho de 2013 quando as pesquisadoras participaram de uma reunião da AVIC. Para a coleta de dados pesquisa documentais se recorreu a fontes como atas, estatutos e outros documentos livremente fornecidos pela Associação estudada. O questionário foi enviado aos 30 voluntários da AVIC, obtendo-se 2I respostas.

A seleção dos sujeitos para a aplicação do instrumento de pesquisa questionário baseou-se na afirmação de Rey (2005), de que, em pesquisa qualitativa, não é o número 
de sujeitos que define a validade dos resultados, mas sim a especificidade do caso estudado. Aplicou-se, portanto, o questionário com voluntários que atuam diretamente na Associação: diretoria equipe de apoio, profissionais da formação humana, profissionais da formação técnica, captadores de recursos e voluntários da equipe de eventos.

A tabulação dos dados foi feita por meio do software Sphinx Léxica. Recebeu-se 2I questionários respondidos representando 7o\% dos voluntários da AVIC. Os dados foram analisados e agrupados em categorias conforme escreve de Godoi (2006). As categorias forma tentativas preliminares de tratamento dos dados, derivadas deles próprios. As categorias foram definidas por agrupamento homogêneo de aproximação de voluntários na AVIC. Priorizou-se, a partir do agrupamento dos dados, atender ao objetivo geral da pesquisa, ordenando com as fontes documentais a análise que alinhou os objetivos secundários e norteou a redação final dos resultados obtidos com a pesquisa. As categorias em torno das quais os dados foram agrupados são: Principais dificuldades referentes à sustentabilidade da AVIC; Visão do voluntário referente à sustentabilidade nas suas dimensões social, econômica e ambiental; Aspectos relacionados aos valores e princípios da AVIC; Observações das práticas relacionadas à sustentabilidade da AVIC.

A partir das escolhas metodológicas utilizadas neste estudo de caso qualitativo e tomando como base a revisão de literatura o desenho do estudo está esquematizado no Quadro 3.

Quadro 3: Resumo dos procedimentos metodológicos adotados na pesquisa.

\begin{tabular}{|l|l|l|l|l|}
\hline \multicolumn{1}{|c|}{$\begin{array}{c}\text { Objetivos da } \\
\text { Pesquisa }\end{array}$} & $\begin{array}{c}\text { Fonte de } \\
\text { Coleta de } \\
\text { Dados }\end{array}$ & \multicolumn{1}{|c|}{$\begin{array}{c}\text { Tópicos } \\
\text { Abordados }\end{array}$} & $\begin{array}{l}\text { Sistematização } \\
\text { dos Dados } \\
\text { Informados }\end{array}$ & $\begin{array}{l}\text { Autores } \\
\text { de Base }\end{array}$ \\
\hline $\begin{array}{l}\text { Identificar quais as } \\
\text { principais dificuldades } \\
\text { encontradas pela AVIC }\end{array}$ & - Observação; & $\begin{array}{l}\text { Principais } \\
\text { dificuldades } \\
\text { referente à }\end{array}$ & $\begin{array}{l}\text { Énfase na } \\
\text { Sustentabilidade } \\
\text { financeira }\end{array}$ & $\begin{array}{l}\text { Sachs } \\
(2008) \\
\text { Seiffert }\end{array}$ \\
\hline
\end{tabular}




\begin{tabular}{|l|l|l|l|l|}
\hline $\begin{array}{l}\text { na visão dos voluntários } \\
\text { que atuam na entidade. }\end{array}$ & $\begin{array}{l}\text { pergunta } \\
\text { fechada }\end{array}$ & $\begin{array}{l}\text { sustentabilidade da } \\
\text { AVIC }\end{array}$ & (2011) \\
\hline $\begin{array}{l}\text { Verificar qual o } \\
\text { entendimento de } \\
\text { sustentabilidade que os } \\
\text { voluntários possuem. }\end{array}$ & $\begin{array}{l}\text { Questionário: } \\
\text { pergunta semi- } \\
\text { estruturada }\end{array}$ & $\begin{array}{l}\text { Visão do voluntario } \\
\text { referente à } \\
\text { sustentabilidade }\end{array}$ & $\begin{array}{l}\text { Consciência e } \\
\text { entendimento } \\
\text { amplo e do que é a } \\
\text { sustentabilidade. }\end{array}$ & $\begin{array}{l}\text { Elkington } \\
(2004)\end{array}$ \\
\hline $\begin{array}{l}\text { Avaliar os principais } \\
\text { pontos fortes da AVIC na } \\
\text { visão dos voluntários. }\end{array}$ & $\begin{array}{l}\text { Questionário: } \\
\text { pergunta } \\
\text { fechada }\end{array}$ & $\begin{array}{l}\text { Aspectos } \\
\text { relacionados aos } \\
\text { valores e princípios } \\
\text { da AVIC }\end{array}$ & $\begin{array}{l}\text { Ênfase na } \\
\text { Humanização }\end{array}$ & $\begin{array}{l}\text { Teodósio } \\
\text { (2002) }\end{array}$ \\
\hline $\begin{array}{l}\text { Identificar a percepção } \\
\text { que os voluntários têm } \\
\text { referente às práticas de } \\
\text { sustentabilidade na } \\
\text { AVIC. }\end{array}$ & $\begin{array}{l}\text { Questionário: } \\
\text { pergunta semi- } \\
\text { estruturada }\end{array}$ & $\begin{array}{l}\text { Observações das } \\
\text { práticas } \\
\text { relacionadas à } \\
\text { sustentabilidade da } \\
\text { AVIC. }\end{array}$ & $\begin{array}{l}\text { Percepção a partir } \\
\text { dos valores da } \\
\text { AVIC. }\end{array}$ & $\begin{array}{l}\text { Elkington } \\
(2004)\end{array}$ \\
\hline
\end{tabular}

Fonte: As autoras com base na literatura.

\section{Apresentação e Análise dos Dados}

Neste bloco o caso é apresentado e analisado. Os dados obtidos das diferentes fontes: documentos, questionário e observação, estão apresentados de maneira integrada, favorecendo a triangulação deles.

\section{Contexto do Surgimento da Associação}

A AVIC está localizada no município de Xanxerê, situado na região Oeste catarinense, pertencente a AMAI (Associação dos Municípios do Alto Irani). O Índice de Desenvolvimento Humano (IDH) do município é de o,8I5. Conforme dados do IBGE (2013), é o segundo município mais importante economicamente do Oeste catarinense. O seu IDSM (Índice de Desenvolvimento Sustentável Municipal) é atualmente de o,635 enquanto que o de Santa Catarina é de o,675, conforme dados da FECAM (2013).

O contexto para a criação do que seria o projeto social Associação Vida Cidadã (AVIC), tem sido favorável para o seu fim, tendo em vista que as parcerias voluntárias, já iniciadas em 2008, são de entidades consolidadas e de pessoas autônomas. Em 2OII, o projeto social passou a ser entidade jurídica, denominada Associação Vida Cidadã (AVIC), com sua finalidade estatutária definida: "criar e fomentar projetos sociais; amenizar as necessidades da população carente, dentro de suas possibilidades; possibilitar a transformação dos empobrecidos, proporcionando uma vida mais digna e cidadã" (AVIC, 2OII). O projeto assumiu a missão de "contribuir com o

\section{Revista Administração em Diálogo} ISSN 2178-0080 
desenvolvimento humano e inclusão social de adolescentes, jovens e adultos, por meio da qualificação humana e profissionalizante."

A AVIC é uma associação civil de caráter educativo, cultural e beneficente de assistência social, sem fins lucrativos e tem, como atividade principal, a defesa de direitos sociais. De acordo com o Estatuto desta Associação, o voluntário precisa inicialmente requerer sua admissão por meio de requerimento endereçado à diretoria da AVIC, no qual se compromete a cumprir o estatuto da AVIC. É facultado à diretoria deferir o pedido de ingresso do interessado por deliberação em reunião específica. O voluntário assume gratuitamente seu trabalho colaborando com na expansão e aperfeiçoamento das atividades da AVIC, bem como dos processos de decisão da instituição.

De acordo com os dados documentais colhidos, a AVIC declara acreditar que a transformação da pessoa acontece por meio de práticas educativas e ações humanizadoras. Defendem que o trabalho em rede possibilita o fortalecimento das relações e da participação e compreendem que a ética consiste, entre outros aspectos, em respeito e acolhida à diversidade cultural e à pluralidade de ideias. Desta maneira, entendem que o comprometimento das pessoas envolvidas possibilita o êxito nas decisões, ações e práticas, que a busca da qualidade e da inovação devem ser constantes.

Outra característica observada é a defesa da itinerância, como capacidade de ser flexível e possuir mobilidade sistêmica. Observou-se que na AVIC o voluntariado é sua força essencial. Neste sentido, a AVIC deixa claro que sua visão de futuro é ter profissionais desenvolvidos integralmente, atuando com consciência e comprometimento na sociedade e com a participação e integração ao voluntariado.

Observou-se, na reunião na qual as pesquisadoras participaram que a AVIC deseja ser referência em ações educativas inovadoras, porém observou-se, da leitura e triangulação dos dados coletados, que há uma tendência ao desequilíbrio no que se refere à dificuldade na sustentabilidade econômica da organização. É possível que os colaboradores voluntários possam sentir-se instáveis com essa situação.

\section{O Voluntariado na AVIC}

Na categoria voluntariado foi analisado o ano de ingresso, número e atuação dos voluntários da AVIC. 
Tabela r: Período de envolvimento com o voluntariado dos respondentes

\begin{tabular}{c|c|c}
\hline Início como voluntariado & Quantidade de citações & Frequência \\
\hline 2008 & 3 & $14,30 \%$ \\
2009 & 10 & $47,60 \%$ \\
2010 & 3 & $14,30 \%$ \\
2011 & 3 & $14,30 \%$ \\
2012 & 0 & $0,00 \%$ \\
2013 & 2 & $9,50 \%$ \\
\hline Total Observados & 21 & $100 \%$ \\
\hline
\end{tabular}

Fonte: Dados da Pesquisa.

O ano de início na AVIC como voluntário pode estar relacionado com os cursos profissionalizantes desenvolvidos. Como em 2009 houve um maior número de cursos oferecidos percebe-se o auge do voluntariado, $\operatorname{com}_{47}, 6 \%$. Outro destaque é que a AVIC, embora sendo uma organização jovem, vem conseguindo manter a adesão de voluntários, o que é fundamental para a sua existência e para a realização de suas atividades.

$\mathrm{Na}$ Tabela 2 apresentam-se as ações de voluntariado nas quais os respondentes estão envolvidos na AVIC, no momento em que a pesquisa foi realizada.

Tabela 2: Ações nas quais atuam os respondentes na AVIC.

\begin{tabular}{c|c|c}
\hline Atuação Voluntária & Qt. cit. & Freq. \\
\hline Formação humana & 7 & $33,30 \%$ \\
Formação técnica & 7 & $33,30 \%$ \\
Equipe de apoio & 6 & $28,60 \%$ \\
Diretoria & 6 & $28,60 \%$ \\
Equipe de eventos & 1 & $4,80 \%$ \\
Captação de recursos & 0 & $0,00 \%$ \\
\hline Total Observados & $\mathbf{2 1}$ & \\
\hline
\end{tabular}

Fonte: Dados da Pesquisa.

Observa-se a atuação preferencial dos voluntários nas atividades finalísticas da AVIC, ou seja, naquelas que remetem para a missão primordial da organização e que, em geral, são as que atraem a atenção daquelas pessoas que buscam o voluntariado. Já a atividade de captação de recursos, uma atividade meio para a organização, parece não ser atraente para a atuação dos voluntários. É possível que este aspecto contribua para explicar as dificuldades financeiras pelas quais passa a AVIC.

\section{Revista Administração em Diálogo} ISSN 2178-0080 
Nesta mesma categoria, que trata dos voluntários e sua atuação, faz-se necessário considerar que a quantidade de citações é superior ao número de entrevistados devido às respostas múltiplas, sendo que participam como voluntários os gestores $(28,6 \%)$ e alguns deles colaboram com outras formas de voluntariado. Ocasionou empate $(33,3 \%)$ entre os voluntários da área da formação humana e da formação técnica. Vale o esclarecimento de que não são os mesmos voluntários que exercem essas duas funções voluntárias. Os mesmos voluntários atuam entre equipe de apoio (equipe que pensa idéias inovadoras, cursos, necessidades emergentes), formação humana e diretoria.

Dificuldades apontadas pelos voluntários

As principais dificuldades citadas pelos voluntários na AVIC, citadas pelos respondentes são estão descritas na Tabela 3 .

Tabela 3: Dificuldades encontradas pelos voluntários da AVIC

\begin{tabular}{l|c|c}
\hline \multicolumn{1}{c|}{ Período de tempo } & Frequência Absoluta & $\begin{array}{c}\text { Frequência } \\
\text { Relativa }\end{array}$ \\
\hline Não resposta & 1 & $4,80 \%$ \\
Sustentabilidade financeira & 18 & $85,70 \%$ \\
Comprometimento da equipe & 3 & $14,30 \%$ \\
$\begin{array}{l}\text { Atendimento as necessidades } \\
\text { emergentes } \\
\begin{array}{l}\text { Consciência e valores } \\
\text { ambientais }\end{array}\end{array}$ & 2 & $9,50 \%$ \\
\hline \multicolumn{1}{c}{ Total } & 0 & - \\
\hline
\end{tabular}

Fonte: Dados da Pesquisa.

Embora sendo uma entidade com fins sociais, com $85,7 \%$ das respostas dos voluntários, a sustentabilidade financeira parece ser a grande dificuldade percebida pelos respondentes voluntários na AVIC. Em seguida citaram o comprometimento da equipe com I4,3\%. A partir do contexto dos voluntários participantes da pesquisa, a AVIC não tem seu foco na geração de lucro ou excedentes, embora necessite de recursos. Esta visão que tende ser idealizada, talvez dificulte a compreensão do voluntariado de que há necessidade de equilíbrio entre a atuação humanitária e a sustentabilidade econômica. A aparente contradição entre arrecadar recursos e o trabalho altruísta de formação humana ou técnica, precisa ser equacionada, de maneira coerente com os valores dos voluntários, 
de forma a gerar recursos que possam contribuir para a manutenção da AVIC e de suas atividades.

Ao observar as atas e os documentos dos balanços econômicos da AVIC, capturou-se uma solicitação, por parte da tesouraria da Associação, de um comprometimento e esforço maior para melhorar as receitas da AVIC, pois desta maneira poderia atender um maior número de pessoas com cursos profissionalizantes, ou seja, atender de maneira adequada a sua finalidade social.

Neste sentido, a literatura aponta que a maior dificuldade enfrentada pelo Terceiro Setor, tanto as organizações que captam seus recursos financeiros junto ao Estado, como as que captam de empresas privadas ou de pessoas físicas, é a sustentabilidade financeira. De acordo com Falconer (I999), o gestor do Terceiro Setor precisa conhecer e desenvolver todas as possibilidades existentes para obter recursos de forma contínua e sem dependência a uma única fonte de financiamento. Estes recursos podem vir por meio de ações filantrópicas ou comerciais, em pequenos ou grandes volumes, pontuais ou constantes, sendo que cada forma tem o seu potencial, suas limitações e seus caminhos mais adequados. Falconer (I999) destaca que a sustentabilidade não se limita à capacidade de captação de recursos para garantir sua sobrevivência, mas também à forma eficiente de melhorar os resultados alcançados e garantir que a entidade continuará a contar com o apoio dos atores no território onde se encontra.

Neste aspecto, os dados da pesquisa apontam a sustentabilidade financeira como uma das principais dificuldades, identificadas pelos voluntários, da AVIC. A Associação organizou, em 20IO, uma equipe de captação de recursos, que, desde então, tem iniciativas junto à gestão da entidade atuando de forma a buscar novos recursos.

Observou-se na reunião da qual as pesquisadoras participaram, que os voluntários relatam a dificuldade de autônomos e entidades efetuarem doações, alegando haver muitos impostos e muitas entidades solicitando ajuda. A impressão que permanece é de uma competição de entidades sociais solicitando colaboração, realizando eventos junto à comunidade para poderem sobreviver.

A problemática do financiamento do Terceiro Setor permanece em discussão, já que o seu serviço é gratuito ao usuário, mas, para oferecê-lo, a entidade tem custos. Uma 
das possíveis soluções, apontada pelos respondentes, foi a efetivação de parceria com instituições bancárias por meio de assinatura de convênio para débito automático, permitindo assim que a AVIC tenha a possibilidade de divulgar para toda a comunidade a opção das pessoas fazerem suas doações por meio de débitos automáticos mensais em suas contas, de acordo com os valores por elas autorizados. Toda pessoa que aceitar a opção será contemplada com um brinde (chaveiro sustentável) da AVIC. A Diretoria aceitou a sugestão trazida e já está em implantação esta parceria, tendo em vista o aprimoramento dos objetivos e missão da entidade social. Outras possibilidades de equacionamento desta problemática precisam ser melhor identificadas e discutidas pelos membros da AVIC.

\section{Pontos Fortes Percebidos pelos Respondentes na AVIC}

Neste avaliou-se os pontos fortes que os respondentes voluntários percebem na AVIC e também o grau de satisfação deles pela atuação na associação.

Tabela 5: Pontos fortes da AVIC percebidos pelos respondentes

\begin{tabular}{l|c|c}
\hline \multicolumn{1}{c|}{ Pontos fortes } & Quantidade de citações & Frequência \\
\hline Humanização & 19 & $90,50 \%$ \\
Transformação & 11 & $52,40 \%$ \\
Inclusão social & 14 & $66,70 \%$ \\
Prioridade para as necessidades & 6 & $28,60 \%$ \\
emergente & 3 & $14,30 \%$ \\
Captação de recursos & 10 & $47,60 \%$ \\
Trabalho em equipe & 3 & $14,30 \%$ \\
Consciência ambiental & $\mathbf{2 1}$ & $100 \%$ \\
\hline Total de observados & &
\end{tabular}

Fonte: Dados da Pesquisa.

A força da organização AVIC tem um destaque de 9o,5\% na ótica dos seus voluntários em humanização. Em seguida, a inclusão social, sendo 66,7\%, a transformação com $52,4 \%$, o trabalho em equipe com $47,6 \%$, a prioridade para necessidades emergentes com $28,6 \%$ dos voluntários que consideraram um ponto forte. A consciência ambiental e a captação de recursos estão em último, com I4,3\%. Chama a atenção que nos documentos, identidade da AVIC, as necessidades emergentes são algo muito presente, traçado como um dos valores principais. Observa-se que apenas o6 de 2I 
voluntários consideram isso como um ponto forte. Este ponto é fundamental, pois dele nascem os pensamentos da equipe de apoio e da gestão, partem as ideias inovadoras, novos cursos profissionalizantes, novos públicos-alvo, novas frentes, a partir de necessidades emergentes.

Quanto à satisfação, ao questionar como o voluntário se sente nesta organização, os dados mostram que existe satisfação. São as respostas: $66,7 \%$ muitos satisfeitos, e 33,3\% satisfeitos. Não houve citação por parte dos respondentes referente a insatisfações em relação à sua atuação como voluntário na AVIC. Esta resposta pode estar relacionada diretamente aos pontos fortes considerados pelos voluntários em 9o,5\% de humanização, conforme Tabela 5. A relação entre os valores individuais do voluntário e a atividade que exerce, reforçam a satisfação e o sentimento de cumprimento de missão, o que pode ser percebido quando da observação pelas expressões de realização dos membros da AVIC com o trabalho realizado.

Tabela 6: Como se sentem os voluntários

\begin{tabular}{l|c|c}
\hline Como se sente & Quantidade de citações & Frequência \\
\hline Insatisfeito & 0 & $0 \%$ \\
Pouco satisfeito & 0 & $0 \%$ \\
Satisfeito & 7 & $33,33 \%$ \\
Muito satisfeito & 14 & $66,70 \%$ \\
\hline Total de observados & $\mathbf{2 1}$ & $\mathbf{1 0 0 \%}$ \\
\hline
\end{tabular}

Fonte: Dados da Pesquisa.

O que possivelmente mantém o voluntariado atuante, mesmo diante de dificuldades, é o conjunto de valores que as atividades da AVIC, na visão dos sujeitos de pesquisa, concretiza. Estes valores ligados à atividade humanística e de promoção social, são percebidos como os pontos fortes, que normalmente tornam o voluntário muito satisfeito em atuar em uma causa, como ficou referenciado pela a pesquisa. Observa-se que no ano de 20o9, ano de início de atividades da AVIC, houve uma variada oferta de atividades, especialmente de cursos, fator que deu visibilidade para a organização e também gerou a necessidade da inclusão de novos voluntários. A humanização (90,5\%), destacada como ponto forte pelo voluntariado respondente da pesquisa traduz a própria identidade do serviço prestado pela AVIC e é o aspecto mais valorizado pelos 
pesquisados. Por meio da análise dos documentos, foi possível observar os Cursos Ministrados pela AVIC e entendidos como atividade concreta do campo de atuação dos seus voluntários.

Um aspecto muito valorizado pelos respondentes é que os cursos são oferecidos de forma itinerante, sendo que estes favorecem um maior aprendizado que possivelmente se dá devido a aproximação dos voluntários aos contextos dos alunos envolvidos nos diversos cursos profissionalizantes. A mudança de contexto e estrutura em cada realidade social permite em certa medida, gerar novos aprendizados que transformam com trocas vivencias, novas compreensões, óticas e posturas diferenciadas a partir das pessoas e suas necessidades, além do curso profissional oferecido.

Tabela 7: Cursos Ministrados pela AVIC

\begin{tabular}{|c|c|c|c|c|}
\hline Atividade & 2010 & 2011 & 2012 & $\begin{array}{c}2013 \\
\text { (até junho) }\end{array}$ \\
\hline $\begin{array}{l}\text { Cursos } \\
\text { Oferecidos }\end{array}$ & $\begin{array}{l}\text { Cabelo e Sobrancelha } \\
(13) \\
\text { Jardinagem e Horto- } \\
\text { Medicinal (8) } \\
\text { Manicure e Pedicure } \\
1 \text { (10) } \\
\text { Manicure e Pedicure } \\
2 \text { (8) } \\
\text { Cabelo (5) } \\
\text { Cuidadores de Idosos } \\
\text { (11) } \\
\text { Horto-Medicinal (12) } \\
\text { Manicure e Pedicure } \\
3 \text { (11) } \\
\text { Jardinagem e } \\
\text { Paisagismo (13) } \\
\text { Artes } 1(10) \\
\text { Artes } 2 \text { (12) }\end{array}$ & $\begin{array}{l}\text { Crochê (8) } \\
\text { Tricô (7) } \\
\text { Manicure e Pedicure (8) } \\
\text { Vivências com Crochê } \\
\text { (14) } \\
\text { Vivências com } \\
\text { Artesanato (15) } \\
\text { Cuidadores de Idosos } \\
\text { (19) }\end{array}$ & $\begin{array}{l}\text { Auxiliar de Cabeleireiro } \\
\text { (6) } \\
\text { Capacitação } \\
\text { Cuidadores de Idosos - } \\
\text { Nível Básico (16) } \\
\text { Grupo Geração de } \\
\text { Renda - Fabricação } \\
\text { Sabão (10) } \\
\text { Manicure e Pedicure } \\
\text { (12) } \\
\text { Básico Metal-Mecânica } \\
\text { (11) } \\
\text { Grupo Gestantes (7) } \\
\text { Grupo Adolescentes (8) } \\
\text { Encontro Vida Cidadã } \\
\text { (62) }\end{array}$ & $\begin{array}{l}\text { Capacitação de } \\
\text { Cuidadores de } \\
\text { Idosos (25) } \\
\text { Curso de } \\
\text { aperfeiçoamento } \\
\text { nível II - área da } \\
\text { beleza. (18) }\end{array}$ \\
\hline Beneficiados & 113 pessoas & 71 pessoas & 132 pessoas & 43 pessoas \\
\hline Voluntários & 56 pessoas & 60 pessoas & 40 pessoas & 30 pessoas \\
\hline
\end{tabular}

Fonte: Elaborado pelas autoras

O enfoque dos cursos citados na Tabela 7 acontece pela mudança de perspectiva trabalhada em um dos valores da AVIC como "necessidades emergentes". Neste contexto a inclusão social e a cidadania, bem como a humanização, são critérios entre os beneficiados, assim como para os voluntários. Estas escolhas são feitas a partir de reuniões realizadas pela AVIC, conforme determina seu estatuto. O componente da

\section{Revista Administração em Diálogo} ISSN 2178-0080 
humanização destaca-se pela existência de disciplinas de formação humana em todos os cursos oferecidos, bem como pelas vivências humanizadoras com todo o voluntariado atuante na AVIC. A crescente ênfase nos aspectos de cuidados e zelos típicos da humanização demonstram não só demandas sociais diferentes, mas também níveis de apreensão da realidade mais aprofundados pela AVIC, tornando-se capaz de perceber não somente as necessidades instrumentais, ditas profissionalizantes, mas, sobretudo aquelas relacionadas a valores substantivos e ligados à necessidades humanas mais prementes.

\section{Dimensões da Sustentabilidade na Visão dos Voluntários da AVIC}

Com relação à percepção dos sujeitos da pesquisa, os voluntários da AVIC, sobre a questão da sustentabilidade, as respostas obtidas foram agrupadas por similaridade e pela sua adesão às dimensões social, ambiental e econômica e também uma visão integrada das três dimensões. Os respondentes estão citados como V (voluntário) seguido do número da entrevista.

Quadro 4: Dimensões da sustentabilidade na visão dos voluntários da AVIC

\begin{tabular}{|c|c|}
\hline Dimensão & Percepções \\
\hline $\begin{array}{l}\text { Sustentabilidade } \\
\text { social }\end{array}$ & $\begin{array}{l}\text { V12 : "Sustentabilidade é toda ação voltada para o social. É um processo a ser } \\
\text { realizado e concretizado a longo prazo". } \\
\text { V13: "Sustentabilidade é o termo usado para definir ações e atividades humanas que } \\
\text { visa suprir as necessidades humanas." } \\
\text { V21"sendo desenvolvido através do projeto várias formações profissionalizantes } \\
\text { gratuitamente". } \\
\text { V6:"Vivemos numa sociedade onde vale o ter. Mas quando uma instituição valoriza o } \\
\text { humano, leva profissão as famílias que menos são favorecidas pela sociedade, assim } \\
\text { trazem na família maior valor sociável". } \\
\text { V10: Estes podendo ser utilizados pela pessoa/família ou vendidos com forma de ter } \\
\text { uma renda familiar ou melhorar essa renda afim de que possam suprir suas } \\
\text { necessidades. }\end{array}$ \\
\hline $\begin{array}{l}\text { Sustentabilidade } \\
\text { econômica }\end{array}$ & $\begin{array}{l}\text { V4: "A instituição precisa andar com as próprias pernas". } \\
\text { V8"maneira de obter recursos para sustentar-se". } \\
\text { V19 "A capacidade de automanutenção". } \\
\text { V20 "Capacidade de se "automanter" sustento por conta própria. }\end{array}$ \\
\hline $\begin{array}{l}\text { Sustentabilidade } \\
\text { Ambiental }\end{array}$ & $\begin{array}{l}\text { V2 "é a preservação do meio em que vivemos, reaproveitando tudo o que temos sem } \\
\text { interferir na natureza". } \\
\text { V3 "Sustentabilidade é o uso de recursos naturais com responsabilidade sem } \\
\text { comprometer as gerações futuras". } \\
\text { V10: "Sustentabilidade, são atividades realizadas visando a utilização de meios e } \\
\text { recursos naturais sem agredir o meio ambiente e a reutilização de outros materiais } \\
\text { (recicláveis ou não) para fabricação/confecção de equipamentos, móveis entre outros. } \\
\text { V15: "Realização de projetos com preocupação ambiental". }\end{array}$ \\
\hline
\end{tabular}

\section{Revista Administração em Diálogo} ISSN 2178-0080 


\begin{tabular}{|c|c|}
\hline $\begin{array}{l}\text { Integração das } \\
\text { sustentabilidades }\end{array}$ & $\begin{array}{l}\text { V1: "penso que a palavra deriva de sustentar e, por isso, creio que seja a pessoa ou } \\
\text { entidade que é capaz de criar meios para se sustentar (se manter), quer psicológica, } \\
\text { moral ou financeiramente". } \\
\text { V5 "É um equilíbrio entre várias questões que permeiam a organização entre as faces } \\
\text { da organização sejam voluntariado, o publico atendido." } \\
\text { V7 "No meu entender a sustentabilidade ainda e meio complexa, mas surgiu para } \\
\text { atender um conjunto de variável independente, pode se dizer a associação deve ter a } \\
\text { capacidade de integrar as questões sócias, energéticas, econômicas e ambientais." } \\
\text { V9 "Penso na sustentabilidade como forma e/ou estratégia para manter um serviço em } \\
\text { um bom funcionamento ou da forma mais correta em mantê-lo. Sempre observando } \\
\text { uma busca de um contexto amplo (social, humano, ambiental e etc). } \\
\text { V16 "O equilibrio entre diversos setores da sociedade e do mundo, como o respeito à } \\
\text { natureza, a economia a serviço da vida de todos, a defesa do Planeta e a humanização } \\
\text { com relações de igualdade, direito e ética." } \\
\text { V11"Sustentabilidade no meu entendimento é um desenvolvimento presente garantindo } \\
\text { o futuro das próximas gerações, partindo de uma prática sustentável para um bem } \\
\text { comum. Sustentabilidade ambiental ou financeira." } \\
\text { V17 "Sustentabilidade é o poder de manter algo "vivo"- "concreto" por muito tempo" } \\
\text { V18"Prática que preservem a vida em toda a sua totalidade". }\end{array}$ \\
\hline
\end{tabular}

Fonte: Dados da Pesquisa.

Evidencia-se, entre os sujeitos da pesquisa, a predominância do entendimento de sustentabilidade pela integração das dimensões da sustentabilidade (econômica, social, ambiental) com enfoque predominante na dimensão social, conforme pode ser observado no Quadro 4. Esta dimensão está diretamente relacionada a atividade fim da AVIC e faz parte de sua própria identidade organizacional. Parece ser coerente que os seus membros percebam as questões sociais da sustentabilidade com mais intensidade, embora também consigam refletir a sustentablidade como um conjunto articulado de diferentes dimensões.

Quanto ao entendimento das dimensões da sustentabilidade, observa-se que como o perfil dos pesquisados é de escolaridade, em sua maioria, de nível superior, pois se trata de profissionais educadores, médicos, advogados, bancários, psicólogos, enfermeiras e assistentes sociais, este fator pode favorecer um entendimento abrangente, adquirido também na prática profissional e não somente na atividade de voluntariado. Talvez o alinhamento do entendimento das dimensões da sustentabilidade de cada voluntário, possa facilitar facilite um reposicionamento e forma de atuação mais abrangente para a AVIC, o que favoreça a adesão de novos membros e a captação de recursos necessários para a sua continuidade.

Com relação à observação de práticas em sustentabilidade na AVIC, os voluntários pesquisados tem uma percepção que está sintetizada no Quadro 5 .

\section{Revista Administração em Diálogo} ISSN 2178-0080 
Quadro 5: Práticas de sustentabilidade na AVIC percebidas pelos sujeitos de pesquisa

\begin{tabular}{|c|c|}
\hline Voluntário & Percepção de práticas de sustentabilidade na AVIC \\
\hline V1 & $\begin{array}{l}\text { "[...] sempre recicla através de formação os colaboradores e ademais, procura fazer ações } \\
\text { com as opões e recursos que tem disponível". }\end{array}$ \\
\hline V2 & "[...] a fabricação de sabão artesanal." \\
\hline V3 & $\begin{array}{l}\text { "A AVIC trabalha principalmente com a questão social, no qual trabalha com formação } \\
\text { humana, no sentido de que os cursos ofertados pela AVIC possam ser ecologicamente } \\
\text { corretos e socialmente justos". }\end{array}$ \\
\hline V4 & $\begin{array}{l}\text { "Os próprios formandos (que recebem os cursos) começam a participar como voluntários e se } \\
\text { forma a corrente humana, popocia (propicia) mundo a propicia sustentabilidade Mesmo que } \\
\text { os formandos não se tornem voluntários, estes na sociedade multiplicam relações humanas." }\end{array}$ \\
\hline V5 & $\begin{array}{l}\text { "Quando pratica o trabalho em equipe, atende as necessidades que existem e quando busca } \\
\text { estratégias sadias para sobreviver". }\end{array}$ \\
\hline V6 & $\begin{array}{l}\text { "Tem o respeito pelo humano, ajuda as famílias em sei bem estar, profissionaliza, informação } \\
\text { e prestação de serviço pessoas carentes, isso é, muito gratificante, na qual busca na } \\
\text { sociedade espaço e valorização. Buscando sempre a melhor forma de se trabalhar, como por } \\
\text { exemplo, utilizando matérias recicláveis demonstrando uma educação ambiental e } \\
\text { sustentável." }\end{array}$ \\
\hline V7 & $\begin{array}{l}\text { "No social e econômico, com recursos naturais capacitando o ser humana interagir com a } \\
\text { sociedade e um aprendizado para o mundo." }\end{array}$ \\
\hline V8 & "[...] a busca de voluntários." \\
\hline V9 & $\begin{array}{l}\text { "No tempo em que atuei como voluntaria penso que a maior preocupação era o de } \\
\text { proporcionar ou provocar a conscientização através de trabalhos que ocasionasse a reflexão. } \\
\text { Além da parte prática das oficinas, por exemplo, sempre tinham momentos que se trabalhava } \\
\text { a parte do cuidado com o meio ambiente, reciclagem e etc..." }\end{array}$ \\
\hline V10 & $\begin{array}{l}\text { "Cuidado no uso dos materiais didáticos, reutilização dos materiais de uma oficina para outra, } \\
\text { contribui para a profissionalização e conhecimento das pessoas no intuito que estas se } \\
\text { qualifiquem para o trabalho." }\end{array}$ \\
\hline V11 & $\begin{array}{l}\text { "Que eu tenha conhecimento mais aprofundado não, lembro que teve algumas oficinas de } \\
\text { reaproveitamento de óleo de cozinha e ervas medicinais. }\end{array}$ \\
\hline V12 & $\begin{array}{l}\text { "[...] a valorização do ser humano é a primeira prática por meio de cursos oferecidos. Os } \\
\text { cursos proporcionam mais do que um currículo para conseguir um emprego, proporcionam a } \\
\text { auto estima, a valorização da pessoa, sua relação pessoa e social, o cuidado com o meio } \\
\text { ambiente por meio dos materiais utilizados. O material ajuda a pessoa desenvolver seu } \\
\text { trabalho, e não escraviza a pessoa." }\end{array}$ \\
\hline V13 & "Está comprometida com as necessidades humanas." \\
\hline V15 & "Utilização de material em telas e uso racional de folhas A4.". \\
\hline V16 & $\begin{array}{l}\text { "Na medida que atua como serviço de amor que transforma, buscando contribuir na } \\
\text { construção social e na construção de valores verdadeiros." }\end{array}$ \\
\hline V17 & $\begin{array}{l}\text { "[...] a AVIC está sempre buscando recursos para que a associação permaneça por muito } \\
\text { tempo com suas atividades." }\end{array}$ \\
\hline V18 & $\begin{array}{l}\text { "[...] valorização da vida, formação humana, respeito, consciência ambiental, cursos } \\
\text { desenvolvidos, sustentabilidade financeira na forma de captação de recursos." }\end{array}$ \\
\hline V19 & "Organização, desprendimento" \\
\hline V20 & "[...] captação de recursos através de promoções, eventos..." \\
\hline V21 & "[...] dando oportunidades a pessoas carentes, ao longo de suas vidas." \\
\hline
\end{tabular}

Fonte: Dados da Pesquisa.

No que se refere às práticas de sustentabilidade observadas pelos voluntários na AVIC observa-se que parece existir um pensamento abrangente, ; muito mais que a defesa do triple botton Line, ou das dimensões social, ambiental e econômica da

\section{Revista Administração em Diálogo} ISSN 2178-0080

Programa de Estudos Pós-Graduados em Administração Pontifícia Universidade Católica de São Paulo 
sustentabilidade $\left(\mathrm{V}_{7}, \mathrm{~V}_{\mathrm{I}} 8, \mathrm{~V}_{20}, \mathrm{~V}_{\mathbf{5}}, \mathrm{V}_{2}\right)$. Percebem-se também algumas práticas de conscientização e dos valores identitários da organização, comprometidos com os direitos humanos, com a cidadania, com a ética e com a satisfação das necessidades básicas da população. O voluntariado observa e valoriza ações que são coerentes com os valores da AVIC ( $\left.\mathrm{V}_{19}, \mathrm{~V}_{\mathrm{I}}, \mathrm{V}_{4}, 2 \mathrm{I}, \mathrm{V8}\right)$.

Os pesquisadores observaram na AVIC que a adesão à causa da organização está relacionada à possibilidade de atuar na transformação da realidade social dentro daquilo que está ao alcance do voluntário e atendendo aquelas necessidades que percebe como mais emergentes. A decisão sobre o campo de atuação é tomada, como já foi citado, por consenso, nas reuniões, a partir do compartilhamento das percepções dos voluntários e do que seja o problema a enfrentar.Observou-se pela análise dos dados obtidos nas diferentes fontes de pesquisa (observação, questionário, documentos) que a sustentabilidade, na visão dos pesquisados, se dá no cotidiano das ações da AVIC, sem, contudo, estar explicitada como conceito.

\section{Considerações Finais}

Com o objetivo geral de identificar quais as principais dificuldades encontradas pela AVIC, na visão dos voluntários que atuam nela, constatou-se que, na visão dos sujeitos da pesquisa, a principal dificuldade da Associação é a sustentabilidade financeira, entendida como a base de sustento de recursos para dar continuidade e expansão às atividades da organização.

$\mathrm{Na}$ perspectiva dos respondentes, o seu ponto mais forte da AVIC é a humanização nas suas ações. Os seus voluntários consideram-se todos satisfeitos ou muito satisfeitos com os serviços oferecidos e acreditam que as práticas da AVIC estão relacionados aos valores da organização.

Os resultados obtidos possibilitam observar que os voluntários pesquisados têm um entendimento da sustentabilidade de maneira integrada, percebendo como relevantes as dimensões econômica, social e ambiental. Observou-se uma tendência à preferência para a sustentabilidade social o que é coerente com a atividade finalística da AVIC. Apesar dos voluntários terem a percepção de que a dimensão econômica é importante para a organização, nenhum atua na captação de recursos, tão necessária para 
a sobrevivência da instituição, ficando evidente que a problemática da AVIC parece estar voltada para a sustentabilidade econômica, uma vez que a falta de recursos repercute na continuidade da atuação da entidade.

A falta de recursos para execução dos cursos profissionalizantes da AVIC pode ser um dos o fatores determinantes para a inviabilidade da realização dos mesmos, o que traria resultados negativos para a sociedade xanxerense e entorno, uma vez que a grande maioria dos cursos profissionalizantes são exclusivamente ministrados na região pela AVIC. É evidente que pela aceitação e credibilidade da AVIC, os cursos têm oportunizado melhoria na qualidade de vida dos cidadãos, criando oportunidades de empregabilidade, maior auto estima para os alunos e melhor assistência profissional aos idosos (no caso do curso de cuidadores de idosos) e principalmente aspectos relacionados à humanização.

Faz-se necessário abrir amplo debate e busca de soluções para a questão da captação de recursos entre os gestores e membros da Avic, de forma a gerar ideias de superação desta que hoje é vista como principal ameaça à continuidade desta importante organização. A percepção de que captar recursos para efetivar as causas sociais da AVIC está alinhada com a atividade finalística da Associação e com seus ideais precisa ser trabalhada, pois os voluntários demonstraram largo comprometimento com as causas defendidas pela AVIC, mas baixa adesão no que se refere ao trabalho de buscar formas de financiamento para a manutenção destas atividades.

É possível que os gestores da AVIC possam aproveitar a visão integrativa e favorável das dimensões da sustentabilidade de seus membros para estabelecer práticas formativas e novas ações de maior lastro no sentido de atendimento destas dimensões na prática de ações sociais.

Essas contribuições também podem ser utilizadas para provocar debates junto a organizações do Terceiro Setor, referente às possibilidades de utilizar os objetivos mobilizadores do desenvolvimento sustentável como pano de fundo para uma ação social de fato inclusiva e para com o gerenciamento das competências do voluntariado de maneira profícua. Observou-se que o simples responder ao questionário já gerou oportunidade de aprendizado aos voluntários participantes, favorecendo momento de reflexão sobre suas práticas e contribuições e despertando para novas maneiras de 
contribuir para com a associação. Esta mobilização pode avançar para encontrar possíveis formas de sustentabilidade financeira para a associação, revertendo assim à fragilidade e contribuindo para a perenidade da AVIC.

Merece destaque o caráter itinerante dos cursos ministrados pela AVIC, o que oportuniza a muitos cidadãos a oportunidade de participarem dos mesmos. A itinerância permite aos voluntários a aproximação vivencial com a realidade social dos alunos envolvidos nos cursos. Pois, conhecendo melhor a realidade dos alunos tende a facilitar o uso de procedimentos didáticos mais adequados que gerem maiores resultados entre a teoria e a prática.

Uma das limitações do estudo que se converte em possibilidade de melhoria, foi à impossibilidade de verificar, neste espaço de tempo da pesquisa, a percepção dos beneficiados diretos pela AVIC, membros da comunidade. Para os próximos estudos sugere-se, além de ouvir pesquisar os beneficiados pela AVIC, avançar para estudos comparativos acerca da sustentabilidade em outras organizações do Terceiro Setor.

Outra possibilidade de estudos futuros reside na busca por equacionamento da questão da manutenção das atividades deste tipo de associação, assunto que, segundo os ouvidos nesta pesquisa, mais os preocupa em relação à continuidade da AVIC.

\section{Referèncias}

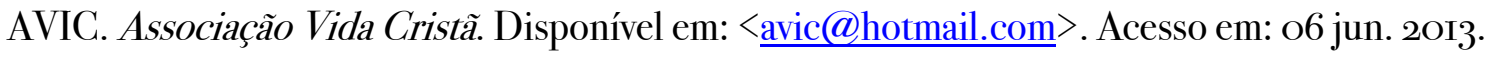

BRASIL. Lei n. 9608 , de I8 de fevereiro de 1998. Dispõe sobre o serviço voluntário e dá outras providências. Disponível em: <http://www.planalto.gov.br/ccivil_o3/leis/Lg6o8.htm> Acesso em: o9 jun. 2013 .

CAMARgOS, Ana Amélia Mascarenhas. Direito do trabalho no Terceiro Setor. São Paulo: Saraiva, 2008.

CAPRA, F. As conexões ocultas: ciência para uma vida sustentável. São Paulo: Cultrix, 2005.

CARDOSO, Ruth. Fortalecimento da sociedade Civil. In: IOSCHPE, Evelyn Berg (Org). $3^{o}$ Setor: desenvolvimento social sustentado. São Paulo: Editora Paz e Terra, I997.

COELHO, Simone de Castro Tavares. Terceiro Setor: um estudo comparado entre Brasil e Estados Unidos. São Paulo: SENAC, 2002.

CMMAD - COMISSÃO MUNDIAL SOBRE O MEIO AMBIENTE E DESENVOLVIMENTO. NoSSo futuro comum. Rio de Janeiro: Fundação Getúlio Vargas, I99I. 
DOHME, Vânia D'Angelo. Voluntariado - equipes produtivas: como liderar ou fazer parte de uma delas. São Paulo: Machenzie, 2OOI.

ELKINGTON, John. Enter the Triple Bottom Line, 2004. Disponível em: $<$ http://www.johnelkington.com/TBL-elkington-chapter.pdf $>$. Acesso em: II jun. 2013.

FALCONER, Andrés Pablo. A Promessa do Terceiro Setor. Um Estudo sobre a Construção do Papel das Organizações Sem Fins Lucrativos e de seu Campo de Gestão. 1999. Disponível em: $<$ http://empreende.org.br/pdf/ONG's,\%2OOSCIP'S\%2Oe\%2OTerceiro\%2OSetor/A\%2Opromess a\%20do\%20terceiro\%2Osetor\%2O-\%2OI.pdf> Acesso em I2 jun. 2013.

FECAM. Federação Catarinense de Municípios. Disponível em: $\langle\underline{\text { http://indicadores.fecam.org.br }>}$ Acesso em: Io mar. 20I3.

FERNANDES, P. V. Impacto ambiental: doutrina e jurisprudência. São Paulo: Revista dos Tribunais, 2005 .

FERNANDES, R. C. Privado Porém Público - O Terceiro Setor na América Latina. Rio de Janeiro: CIVICUS/ Relume Dumará, I994.

FILIPPIM, E. S. Teorias do Desenvolvimento. Joaçaba, Unoesc, mimeo, 2008.

FISCHER, Rosa Maria. ODesafio da Colaboração. São Paulo: Gente, 2002.

FISCHER, R.M.; FALCONER, A.P. Estratégias de empresas no Brasil: a atuação social e voluntariado. Brasília. Programa Voluntários, Conselho da Comunidade Solidária, I999.

FRANÇA FILHO, Geraldo Carvalho. Terceiro Setor: Economia Social, Economia Solidária e Economia Popular - Traçando fronteiras conceituais. Bahia Análises \& Dados. Salvador, SEI v.I2. n.I p. 9-I9 Junho, 2002.

GODOY, Arilda Schmidt. Refletindo sobre critérios de qualidade da pesquisa qualitativa. Revista Eletrônica de Gestão Organizacional(Gestão.Org), v. 3, n. 2, mai./ago. 2005.

GODOY, Arilda Schmidt. Introdução à pesquisa qualitativa e suas possibilidades. In: Revista de Administração de Empresas, v. 35, n.2, Mar./Abr.I995, p.57-63.

Christiane Kleinübing Godoi.; BANDEIRA-DE-MELLO, Rodrigo; SILVA, Anielson Barbosa (Org.). Pesquisa qualitativa em estudos organizacionais: paradigmas, estratégias e métodos. São Paulo: Saraiva, 2006.

IBGE. Instituto Brasileiro de Geografia e Estatística. IBGE Estados. Rio de Janeiro: IBGE/MMA.

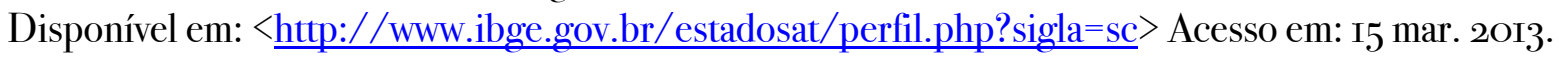

JACOBI, Pedro. Meio Ambiente e Sustentabilidade. In: CEPAM. O município no século XXI: cenários e perspectivas. São Paulo: CEPAM (Centro de Estudos e Pesquisas de Administração Municipal), I999. p. I75-I83.

KISIL, Marcos. Organização Social e Desenvolvimento Sustentável: projetos de base comunitária. In: IOSCHPE, Evelyn Berg (Org). $3^{\circ}$ Setor: desenvolvimento social sustentado. São Paulo: Editora Paz e Terra, I997.

LEWIS, Jordan. Alianças Estratégicas: estruturando parcerias para o aumento da lucratividade. São Paulo, Pioneira, I992.

MENDONCA, Patrícia Maria; ARAUJO, Edgilson Tavares. Sustentabilidade Organizacional em 
ONGs: Os casos do GAPA-BA e do Grupo Brasil a partir das contribuições da Teoria da Dependência de Recursos. Revista Gestão e Planejamento. Salvador, v. I2, n. I, p. II2-I32, jan./jun. 2OII. Disponível em: <http://www.revistas.unifacs.br/index.php/rgb/article/view/II2O/I234>Acesso em I9 jul. 2OI3.

MOURA, L.A.A. Qualidade e gestão ambiental: sugestões para implantação das Normas ISSO I4OOO nas Empresas. 3.ed. São Paulo: Juarez de Oliveira, 2002.

NOLETO, Marlova. Parceiras e Alianças Estratégicas: Uma Abordagem Prática. São Paulo: Instituto Fonte, 2000.

ONU. Organização das Nações Unidas. Nações Unidas no Brasil: $A O N U$ e $o$ voluntariado. Disponível em: <http://www.onu.org.br/a-onu-em-acao/a-onu-em-acao/a-onu-e-o-voluntariado/> Acesso em: o9 jun. 20I3.

PAUlA, Juarez. Uma Agenda Para o Brasil. In: Uma Agenda de Desenvolvimento Humano e Sustentável para o Brasil do Século XXI. PNUD - Instituto de Política, 2000.

PNUD. Programa das Nações Unidas para o desenvolvimento. Programa de Voluntários das Nações Unidas (VNU). Disponível em: <http://www.pnud.org.br/UNV.aspx $>$ Acesso em: I6 jun. 2013.

REY, Fernando Gnovález. Pesquisa qualitativa e subjetividade: os processos de construção da informação. I.ed. São Paulo: Thomson, 2005. V. I.

ROCA, G. J. Solidaridad y voluntariado. Maliaño (Cantabria): Sal Terrae, I994.

SALAMON, Lester. Estratégias para o fortalecimento do Terceiro Setor. In: IOSCHPE, Evelyn Berg (Org). $3^{\circ}$ Setor: desenvolvimento social sustentado. São Paulo: Editora Paz e Terra, I997.

SALAMON, Lester. A emergência do Terceiro Setor - uma revolução associativa global. Revista de Administração, São Paulo v.33, n I, p.5-II, janeiro/março 1998.

SALAMON, Lester; ANHEIER, H. In search of nonprofit sector: the quest for definition's. Voluntas, v3, n.2, p.267-3II, I992.

SACHS, I. Caminhos para o desenvolvimento sustentável. Rio de Janeiro: Garamond, 2002.

SACHS, Ignacy. A riqueza de todos: a construção de uma economia sustentável em um planeta superpovoado, poluído e pobre. Tradução Sérgio Lamarão. Rio de Janeiro: Nova Fronteira, 2008.

SAMPAIO, Helena; RODRIGUES, Lea. Construção e Dinâmica da Parceria nos Programas do Conselho da Comunidade Solidária - mimeo, Programa de Parcerias entre Estado e Sociedade, 1999.

SEIFFERT, Mari Elizabete Bernardini. Gestão Ambiental - Instrumentos, Esferas de Ação e Educação Ambiental. São Paulo: Editora Atlas S.A., 2OII.

SOARES, Helena Isabel Costa. O contributo do voluntariado no apoio aos idosos sós e/ou dependentes do concelho de Ovar. Coimbra, 20I2. Trabalho de Conclusão de Mestrado em Sociologia - Faculdade de Economia da Universidade de Coimbra, Portugal, 2OI2. Disponível em: <https://estudogeral.sib.uc.pt/bitstream/IO3I6/2I4I2/I/Relat\%c3\%b3rio\%2Ode\%2OEst\%c3\%argi o.pdf>. Acesso em: o3 jun.2OI3.

SOUZA, Washington José; MEDEIROS, Jássio Pereira. Trabalho Voluntário: Motivos para sua realização. Revista de Ciências da Administração. V. I4, n33, p. 93-IO2, ago.2OI2. Disponível em: < http://www.periodicos.ufsc.br/index.php/adm/article/view/IgOIg> Acesso em: O2 jun. 2013.

\section{Revista Administração em Diálogo} ISSN 2178-0080 
TEODÓSIO, Armindo dos Santos de Souza. Voluntariado: entre a utopia e a realidade da mudança social. $\quad 2002 . \quad$ Disponível em: <http://www.anpad.org.br/diversos/trabalhos/EnANPAD/enanpad_2002/GPG/GPGI872.pdf $>$ Acesso em: o3 jun. 2013 .

TINOCO, J. E. P; KRAEMER, M. E. P. Contabilidade e gestão ambiental. São Paulo: Editora Atlas, 2004 .

UNIETHOS. Manual Programa de Voluntariado. Disponível em: <http://www.ethos.org.br/ Uniethos/Documents/MnVoluntariado.pdf> . Acesso em: I5 jun. 2013 YIN, Robert. Estudo de caso: planejamento e métodos. Porto Alegre: Bookman, 2005. 